\title{
The interactional negotiation of group membership and ethnicity; The case of an interview with a former slave
}

Dorien Van De Mieroop \& Jonathan Clifton

\begin{abstract}
We examine the way group membership and its relation with ethnicity is interactionally constructed in an interview between an interviewer who presents himself as favorable towards black music and black people and an interviewee who is a former slave. The interview, which took place in the 1940s Deep South in a context in which racial inequality was still institutionally embedded, focused both on the interviewee's memories of slave life and on current life and opinions about music. The discussion of each period is characterized by a different genre: while extended turns and lengthy stories occur while discussing the antebellum period, the discussion of the postbellum period is characterized by short and heavily negotiated question and answer sequences. However, throughout the entire interview, the interviewee maintains coherence by frequently shifting alignments and basing group memberships on quite diverse criteria, as such challenging its relation with ethnicity as initiated by the interviewer.
\end{abstract}

Keywords: group membership, membership categorization analysis, ethnicity, slaves, narrative, context, genre, interview, storytelling, conversation analysis, narrative analysis 


\section{Short bio's of authors}

Dorien Van De Mieroop is an assistant professor at the Catholic University of Leuven (Belgium). Her research focuses mainly on identity construction, both in institutional contexts (e.g. speeches, social work interactions, meetings) and in narratives and life stories. She has published a number of articles on this topic (e.g. in Discourse \& Society, Journal of Pragmatics, Narrative Inquiry, Research on Language and Social Interaction, Pragmatics and Journal of Sociolinguistics).

Jonathan Clifton has a PhD in linguistics from Antwerp University and now works as a lecturer in the Department of Applied Linguistics at the University of Lille 3 (France). His research interests are centred around the themes of workplace interaction and identities-intalk. 


\section{Introduction}

Ethnicity is one of the typical elements of a person's transportable (Zimmerman, 1998) or master identity, which is 'potentially relevant anytime, anywhere' (Zimmerman, 1988: 426). Given the nature of one's identity which is constructed over and over again rather than present in some kind of essentialist way, the word 'potentially' in the previous quote cannot be overemphasized. Indeed, it is clear that nowadays in many situations, a person's membership of a particular ethnic group, as well as of groups based on other aspects of one's transportable identity such as one's age or gender, are not made relevant in the interaction at hand and thus these elements can sometimes quite confidently be disregarded while carrying out discursive analyses. This is, among others, due to the fact that people's words and actions are related to their context of use, and since our current Western society endorses racial equality as an essential characteristic of human rights, it would often be considered morally wrong to foreground ethnicity as a relevant feature of a person, for example to include or exclude him or her from a social group. From a theoretical perspective, it is thus interesting to investigate whether in societal systems which are built on racial inequality, ethnicity is discursively made relevant in a different way. This would be quite logical in institutionally racist societies, since societal group membership is in that case normatively based on criteria such as, among others, ethnicity. For this reason, we aim to analyze an interview that looks back at and is situated in a quite different era, which was characterized by racial inequality. In particular, we are studying an interview with a former slave that took place in 1941. In interaction with the interviewer, the former slave discusses his memories of life on the plantation where he had been a young slave and he also relates his current views on life and music in a society in which racial discrimination was highly institutionalized by means of the 
Jim Crow laws, which 'dominated social life as pervasively and almost as harshly as slavery ever had' (Escott, 1991: 42).

The interview we are studying in this paper was selected from a number of collections of interviews with former slaves that were gathered from the late 1920s onwards for several reasons and with several goals (for an overview, see Yetman, 1967). So far, almost no linguistic studies have focused on slave narratives (for an exception, see Van De Mieroop and Clifton, 2011). On the one hand this may be because of criticisms of the actual interviews, notably concerning the context of the data-collection and the time-lapse between the collection of the data and events discussed, and on the other hand the lack of rigor displayed by many of the interviewers raises concerns as to their objectivity.

Firstly, regarding issues of memory, it is noted that most of the interviews with the former slaves took place in the 1930s and 1940s and so there was not only a serious time lapse between the interviewees' experience of slavery and the time of the interview, thus resulting in a great potential for reflexivity and distancing (Linde, 1993: 124), but it was also the case that most interviewees were children in the days of slavery (Yetman, 1967: 534-535; Escott, 1991: 41). This may have resulted in many stories based on hearsay rather than on personal experience ${ }^{\mathrm{i}}$, which often gave a 'favorably colored' version of life as a slave delivered by people who had not felt 'the full rigors and worst aspects of slave discipline' (Vann Woodward, 1991: 51). Furthermore, the former slaves had reached an advanced age at the time of the interview. This may have affected their ability to narrate past events accurately and consequently, as Spindel concludes, such narratives do not 'provide adequate or reliable understanding of the past' (Spindel, 1996: 261). This is of course problematic from a historical perspective, which is often taken in the above mentioned studies, but from a linguistic perspective this is not a primary concern. This is due to the generally agreed upon fact that 'a narrative of a personal experience is not a clear route into 'the truth"' (Atkinson 
and Delamont, 2006: 166), but rather that narratives construct their own social realities in interaction with the local and global context. Thus, since "truth' is not a property to be treated as an issue in the quality-control of information' (Atkinson and Delamont, 2006: 169) and because we favor a performative approach, which foregrounds the role of the narrative as a 'social phenomenon' (Atkinson and Delamont, 2006: 170), this issue of veracity is bracketed further in this article.

Secondly, as Escott (1991) noted, the conditions and prevailing Zeitgeist under which the data was collected have also been cause for concern about the usability of the narratives as data. For example, it is argued that considering the fact that discrimination and racial inequality were institutionally embedded in society at that time (Hamilton, 2001) and, that since most of the interview data collecting was done by white interviewers, this led to an absolute lack of candor on the part of the former slaves who provided a view of slavery that they thought the white interviewers were looking for (Yetman, 1984; Bailey, 1980). Consequently, as Sekora (1987) argues, all that the interview data represents is a black message in a white envelope in which the authentic black voice is absent. However, since this article not only favors an interactional approach to narratives that foregrounds the coconstructed nature of the narrative in which meaning is 'actively and communicatively assembled' (Holstein and Gubrium, 2003: 68), but since the interactional dynamics of the narrative are one of the focal points of our analyses, this aspect of the interviews is thus explicitly incorporated in the analyses. Special attention is paid to 'the type of relationships that interviewers and interviewees establish between each other and among themselves' (De Fina, 2009: 246), which has also been one of the criteria for selecting the interview for this article (see data description below for more details).

Thirdly, another reason for the limited interest in these slave narratives may be related to the technical aspects of these interviews. For example, it has been argued for the narratives 
that come from the WPA-project ${ }^{\mathrm{ii}}$ that the predominantly white interviewers were at best patronizing or at worst offensive and condescending and that this therefore affected the quality and candor of the data they collected (Vann Woodward, 1991). It is also claimed that by asking leading questions the interviewers sought to get a picture of slavery that suited a white audience (Soapes, 1977). Furthermore, since many of the narratives were not audio recorded but were transcribed by hand, many of the existing transcripts are in fact edited versions of the actual interviews in which transcribers of slave narratives deliberately distorted the content of the transcripts (Blassingame, 1975: 485). Furthermore, on a linguistic level, it is claimed that the data was 'contaminated' either by over-editing the interviewees' words to formal English (Brown, 1991: 39) or by replacing their standard English words with 'typical' dialect phrases (Blassingame, 1975: 486). However, the data used in this study comes from The Library of Congress/Fisk University Mississippi Delta Collection which used audio-recorded data. It is of course of the utmost importance to have direct access to the data so that a detailed interactional analysis can be carried out for which a transcription of the words alone does not suffice. This is not only standard practice in discursive analyses, but considering the criticism leveled at some of the existing transcripts, it is especially important to have the recordings of the data at one's disposal.

Given the criticisms discussed above, it is not surprising that some historians (e.g. Blassingame, 1972) have dismissed the narratives as being of limited use since their reliability as an avenue of research into the veracity of the institution of slavery is in doubt and some even argue that these slave narratives 'can be mined for evidence to prove almost anything about slavery' (Vann Woodward, 1991: 53). However, one meaningful avenue into these data is proposed by Blassingame who states 'they [the researchers] should begin by mastering the skills of the linguist and then systematically examine the internal structure of the interviews' (1975: 487). Such an approach is taken by this paper which takes as its starting point that any 
interview is a situated and interactional event and thus it is naive to assume that the interviewer could simply get ex-slaves to fully and freely discuss the range of their experiences and impressions of life under the slave regime which, as (Yetman, 1967: 535) states, was the aim of the interviews. This is because an interview does not take place in a social vacuum, the interviewers play an important role in the construction of meaning given the fact that their 'neutrality is most likely an impossible aim' (De Fina, 2011: 35) and the interviewees are always susceptible to giving a partial account that puts their actions in a favorable light (cf Linde, 1993) according to who the perceived audience is. Thus, as Edwards and Potter (1992: 24) point out, 'the past is reconstructed according to the functional concerns of the present' and rather than the voice of the interviewee providing a clear window into his or her mind and memory, these cognitive phenomena are discursive products of the interaction which are co-authored by the interviewee and interviewer on a turn-by-turn basis as the interview progresses (cf. Schaeffer and Maynard, 2005). As such, the interview data does not, indeed cannot, provide a 'truthful' account of the memories, thoughts and feelings of the interviewee but it can however provide a co-constructed version of these cognitive phenomena that is achieved in the here and now. Such a temporally situated interactional event (re)creates phenomena such as opinions (Wetherell and Potter, 1992), identities (Potter and Wetherell, 1987) and memories (Lynch and Bogen, 2005) which are practically managed and dialogically organized to suit the interactional circumstances and can change on a turnby-turn basis.

As such using recorded data, gives us access not into some objective reality of 'what it was really like to be a former slave or a Negro in the 1940s' but rather such data gives the researcher an insight into how an ex-slave (re)constructs his thoughts, feelings, memories and identity when interviewed in the context of the 1940s Deep South. This article, then, focuses on the way in which identity, temporally situated in the antebellum and postbellum periods, is 
discursively constructed and negotiated by the interviewer and the interviewee to give a nuanced account of group membership and ethnicity in which the master identities black and white in opposition to each other are not, as one might expect, always made relevant to the interaction. Identity is not considered from a pre-discursive essentialist stance but rather from a social constructionist perspective in which it is locally and discursively constructed within a particular social practice. Consequently, identity is not only considered to be fluid, but it is also resolutely social and this results in the construction of 'a number of contextual selves' (Wetherell and Maybin, 1996: 223) that is far more nuanced than the essentialist assumption that ethnicity, and more particularly a dichotomy between black and white identities, is a priori relevant to the interaction.

\section{Data description}

The interview we selected belongs to a dataset that is part of what is now known as The Library of Congress/Fisk University Mississippi Delta Collection which since 2004 has been housed in the Alan Lomax Collection in the Library of Congress. The collection, assembled in the summers of 1941 and 1942, was the result of collaboration between Alan Lomax and Charles Johnson. Lomax was the Assistant in Charge of the Archive of Folk Song of the Library of Congress and a highly important, but also regularly criticized, figure in the collection of slave narratives (Yetman, 1967) and folk songs (Cohen, 2011), and Charles Johnson was a Professor of Sociology and Director of the Department of Social Sciences at Fisk University, 'the Princeton of black colleges' (Lomax, 1993: xii), in Nashville, Tennessee. The collaboration came about because, as Lomax points out himself, given the context of the Jim Crow South in the 1940s, 'it was clear the Southern blacks would not readily confide in a white folklorist' (Lomax, 1993: xii). In order to avoid this stumbling block, which had been a major criticism of the WPA collection of narratives, Lomax sought to work with black 
colleagues to resolve this problem. Given Lomax's interest in music and his status as an ethnomusicologist, the main aim of the Mississippi Delta Project was to explore the musical habits of the black community in the Delta and to document its history and socio-cultural background (Library of Congress, 2011). Amongst other data relating to the project, The Library of Congress now holds 96 phonographic discs, made on contemporary recording machines. The particular interview discussed in this paper was made in September 1941 in Mound Bayou, Mississippi. It consisted of a former slave, George Johnson, whose age was unknown but considering that he was brought up on Jefferson Davis' plantation during the antebellum period, he must have been well into his $80 \mathrm{~s}$ at the time of recording. He was interviewed by Dr. Charles Johnson, who was an important figure in establishing the Fisk collection of slave narratives (Yetman, 1967: 540-541). Also present at the interview are Lewis Jones, who was Charles Johnson's 'highly skilled field assistant' (Lomax, 1993: xii) at the time, Alan Lomax and his wife Elizabeth. With the exception of a few questions proffered by Elizabeth Lomax, Charles Johnson asked the vast majority of the questions. So, basically, we have an interview between Charles Johnson and George Johnson with an overhearing audience of three people. Due to the limited capacity of the discs of the portable recording machines (Lomax, 1993: xi), the interview is divided into 6 sections. In total, it consists of 18,103 words and lasts for 77.38 minutes. This paper starts from both the audio files and the transcriptions that can be found on the Library of Congress website which adheres to 'the accepted practice for professional folklore scholarship' and is presented in Standard English ${ }^{\mathrm{iii}}$. We first corrected these transcriptions and then added conversation analytic transcription symbols (cf Antaki, 2002) in order to represent the way the interview was voiced in more subtle ways. Both the original audio version of the interview and the transcription are available on the Library of Congress website ${ }^{\mathrm{iv}}$. 
We selected this interview because it is one of the most extensive interactions of the collection and it contains a significant number of elaborate discussions of a range of different topics. This may be due to a whole set of reasons related to personal or situational characteristics which cannot be traced, but one of these reasons may be that the main interviewer, Dr. Charles Johnson, was black. It has been suggested that interviews made by black interviewers led to better quality interviews in terms of openness and depth of responses (Vann Woodward, 1991: 52). This is of course not prediscursively guaranteed, and moreover, the overhearing, partially white audience may also have played a role in the interviewee's perception of the interviewers' expectations. However, when looking at some of the characteristics intrinsic to the interview, we could conclude that the interviewer constructed this interview as a respectful, in-depth interaction, as the absence of patronizing questions and the use of impartial ethnic labels indicates. The latter were even quite emblematic: on the one hand, the interviewer discursively constructs the interview as neutral through his extensive use of the politically correct term colored people, whereas, on the other hand the interviewee systematically uses the term nigga(s), which implicitly refers to the days of slavery and thus has an inferior connotation in this context (cf Whooley, 2006: 309). By selecting such data, we aim to complement previous work, for instance by Whooley (2006) who contrasted two quite extreme examples of pro- versus contra-abolitionist narratives, with the analysis of a more nuanced dataset.

\section{Research question}

As mentioned in the beginning of the article, we focus on the way categorization in social groups, and, related to that, ideological stances on ethnicity are talked into being and negotiated by the interviewer and the interviewee in relation to their context, both of the time of the interview and of slavery times. We chose this topic because of the fact that both 
contexts (i.e. antebellum and postbellum periods) are characterized by institutionalized racial inequality and we thus aim to look at the way the interviewee, as a former slave, negotiates the topic of group membership and ethnicity with the interviewer, who belongs to the same ethnic group but who is of course not part of the same social group as the interviewee, due to for example his age, education and profession. We thus look at the way ethnic and social group membership is negotiated by the interviewer and the interviewee, both regarding themselves and others throughout the interview.

The notion of social group will be considered here from the point of view of membership categorization. Whilst it is beyond the scope of this paper to give a detailed description of membership categorization analysis (MCA) and the debates that surround it, suffice to say that the origins of MCA date back to Harvey Sacks' early work in the 1960s (e.g. Sacks, 1972; 1986; 1992) which sought to explicate the way in which members use categorization as a resource to make sense of everyday life. Despite controversy (cf. Schegloff, 2007), researchers (see, for example, Hester and Eglin, 1997a, Housley and Fitzgerald, 2002 and Lepper, 2000) have particularly developed the notion of categorizing (as a verb) rather than categorization (as a noun). From this interactional perspective, categories and their predicates (i.e. clusters of expectable features such as actions, character traits, ways of thinking, motivations, dress codes, locations and so on that can be inferred from categorization) are something that are not prediscursive but are features that are negotiated in talk and which therefore "provide methods for assigning actors and actions their proper identities, methods, in short, for reading history and society" (Hester and Eglin, 1997b: 162). Social groups from this perspective are thus forms of categories (collectivities in Jayyusi's (1984) terms) whereby predicates associated with, claimed by, or projected on, participants are not oriented to as something individualistic, but rather predicates are oriented to as something that are occasioned as representing the activities and character of other people as 
well. Such categorizing thus has the effect of talking into being groups to which participants are occasioned as 'belonging' and thus categorizing can make group identity relevant to the interaction as a morally accountable matter (Jayyusi, 1984: 48). This category work is, of course, negotiable and participants can either align or disalign with it, which we take to be related both to the way in which participants position themselves relative to each other in terms of affective and relational stances, and to what can be derived from the way in which they manage the sequential development of the interaction by relating utterances to each other (Schiffrin, 1993: 233).

More specifically, we divide the analyses in two sections which are both related to the two main contexts, which are reflected in two time periods, namely pre- and post Civil War periods. This temporal division also turns out to be reflected in a difference in genre. In general, this interview should be regarded as a mix of short question and answer sequences and of partial narratives of personal experience. This can be related to the fact that on the one hand, the interviewee was asked to give his views on, and relate his experience of life and music as part of the folkloristic goals of the interview. These parts of the interview contain a number of typical autobiographical stories, which can be characterized as 'non-shared, personal experience past events stories' (Georgakopoulou, 2007: 17). However, since these parts of the interview often also probe for facts and opinions, they are mostly characterized by a number of highly interactional question and answer sequences, in which the turns of the interviewee are often quite short. On the other hand, the parts of the interview that focus on the pre-Civil War period often contain much lengthier answers by the interviewee, but these stories are often semi-autobiographical. Next to stories of personal experience, we find several different genres of stories. Some of these stories can for example be regarded as hearsay stories (see Van De Mieroop and Clifton, 2011), some as 'generic narratives', in which the uniqueness condition of a narrative of personal experience is suspended (Baynham, 
2006: 382) and others still as 'habitual narratives', which relate typical events that are used 'to build a holistic picture of the past that speaks for itself' (Carranza, 1998: 305). This diversity in genres is not surprising, since the interviewee's personal recollection of the pre-Civil War period was generally limited to childhood memories, which can be derived from the time lapse of 76 years that occurred between the end of the Civil War and the moment the interview took place (see discussion above). Of course, memories particularly related to childhood (e.g. children's games) were usually not the focus of the interviewer's questions ${ }^{v}$ which mostly probed for the typical characteristics of adult slave life, with which the interviewee obviously had fairly limited experience. In conclusion, this diversity provides quite an intriguing dataset, since it is thus possible to analyze the construction and negotiation of group membership and its relation to ethnicity not only across different contexts, but also across these different genres.

\section{Analyses: constructing social groups}

This section is divided in two parts. The first part deals with the interviewee's recollections of life on Jefferson Davis' plantation during the antebellum period and the second part focuses on events during the postbellum period and at the time of the interview. Both analytical parts start from the premise that the data are to be considered as an interactional achievement to which both interviewer and interviewee contribute in a substantial way. Given the fact that interview as a whole was mostly oriented to music and folklore, it is quite logical that this part of the analyses is lengthier than the first part focusing solely on the antebellum period.

\section{Pre-Civil War period}


In this section, we focus on a number of fragments which are highly relevant from a categorizational perspective and which demonstrate the interviewee's construction of social groups.

At the beginning of the recordings, the interviewer asks a personally oriented question which implicitly foregrounds the interviewee's former identity as a slave, since he asked the interviewee how he got his name (line 45), which was typically assigned to slaves by the slave owners (Puckett, 1990: 171). So it is not surprising that in his answer (line 47: I got my name from President Jeff Davis), the interviewee immediately links this topic to his slave owner. Immediately after this response, the interviewee shifts the focus of this topic from himself to Jeff Davis and this is the start of a lengthy story of 119 lines in which the interviewee consistently uses an impersonal perspective, except from the first line of course, and in which he, by means of stepwise topic shifts, gives quite an elaborate discussion of life at Davis' plantations. In this story, the construction of the 'benevolent' master identity, which is quite stereotypical (Whooley, 2006: 310), is central and many elements are discussed as an illustration of this identity construction, as for example the topic of the education the slaves received at the plantation. This discussion also entails an implicit construction of social groups, as the analysis of this extract demonstrate.

Extract 1: (turn by the interviewee)

And ah, had all those niggas from different places,

90 on those plantation to come to that school.

$91 \quad$ Nice school.

92 He give them all a formal education.

93 When they all got $\uparrow$ free, they could take care (of) theyself.

((three lines omitted of which the transcription is uncertain)) 
While describing the education of the slaves at the school on one of Davis' plantations, the interviewee clearly does not align himself with the group of slaves. He consistently refers to them in a non-involved, impersonal way, either by using the third person pronoun (singular forms in line 99 and plural forms in lines 92-93) or by referring to them as those niggas (line 89), a formulation in which the demonstrative pronoun almost literally shows the interviewee's distance from the group of slaves (Stivers, 2007). He even uses this pronoun to refer to the plantation (line 90), as such thus even implicitly distancing himself from slave life in general in the beginning of this extract. However, the scope is gradually widened again in lines 97-98 by means of the use of the Extreme Case formulation (Pomerantz, 1986) everyone, which is first still qualified as everyone learned, thus referring to the slaves who had received an education, but which is then quickly generalized to everyone. Given the immediately surrounding context, in which the verb to obey occurs twice (line 98 and 99) and in which Davis is referred to as master Jeff twice as well (lines 97 and 99), the scope of these Extreme Case formulations is limited to the group of slaves, who are constructed here as one group that collectively admires and obeys the slave owner. Not only by discussing the slaves' admiration and their unfailing obedience, as indicated by the geographical Extreme Case formulation (line 99: don't care where he's going), but also by describing Davis' actions by means of positive adjectives (line 91: nice, line 92: formal), the slave owner is presented in a positive light and his identity as a 'good master' is implicitly constructed.

However, further down in the same story, which the interviewee relates uninterruptedly, the scope of the previous Extreme Case formulation everyone is widened even more and transcends not only the group of slaves versus that of the free, but it even transcends ethnicity, as the interviewee states explicitly in the following extract. 
Extract 2: (turn by the interviewee)

121 They a:ll obey master Jeff.

122 The white people would always go up the bank

$((\text { three lines omitted }))^{\mathrm{vii}}$

126 They would always obey him all the time.<(.)

$\rightarrow \quad 127>$ White and black< (.) They gave him honor.

In the abstract of this short story, the interviewee presents the gist of his story, which is fairly similar to his statements in the previous story (see e.g. line 98). Again, by means of the Extreme Case formulation all and its lengthened pronunciation, the interviewee stresses the prevalence of obedient behavior towards the slave owner. The interviewee then provides an additional illustration which implicitly qualifies this initial Extreme Case formulation as surpassing race boundaries, since the protagonists in this story are the white people (line 122). He first concludes the story by repeating the abstract almost literally in the coda (line 126), which is again characterized by two, in this case temporal, Extreme Case formulation (always and all the time). The accumulation of Extreme Case formulations throughout these two extracts contribute to the presentation of this story as objective (Pomerantz, 1986: 219). In spite of the lack of clarity in the complicated action (see note 5), the final line of this extract is quite explicit in that it emphatically surpasses racial boundaries and groups both black and white people as one collective category that can be characterized as admirers of master Jeff. As such, ethnicity is explicitly bracketed in this initial story of the interview and the construction of one collective group of admirers as opposed to the 'benevolent' master is foregrounded.

However, this construction of social groups is quite complex, as the final extract for this antebellum period also demonstrates, since it shows a clear disalignment of the interviewee with black people during slavery times. This extract is taken from the 
interviewee's answer to a typically folklore oriented question by the interviewer, which was directed at the discussion of ghost stories that the slaves told each other (lines 1772-1774: Did they tell ghost stories? What kind of stories did they tell when you sat around the fire at night?). In the first lines of this extract, the interviewee is telling the final lines of the ghost story he has been relating.

\section{Extract 3:}

1786 IE >And the other fellow head toward the spirit

1787 he get home and tell that tale about that spirit. $<$ That's

1788 all right. (2.9) Nigga have so many things he tell that ain't so.

1789 IR ((briefly chuckles))

1790 IE Pass the steam and the water out there (he ain't)

1791 he ain't think. He ain't thought. (.) White man he ain't got thou-

1792 that ki- kind of thought in his head. (.) Nigga ai[n't

1793 IR

[White man

1794 doesn't have that kind of thought in his head?=

1795 IE $=$ No:: $>$ He ain't got nothing like that in his head. $<($.

$1796 \quad$ No. $>$ He ain't got nothing like that in his head. $<($.

1797 They put it off just (.) 个 air. (1.7) Now you know

1798 个I never seen spirit in my $\uparrow$ life (.)

After finishing the story in lines 1786-1788, there is quite a long pause and then the interviewee adds his own evaluation of the story (line 1788). In this evaluation, he provides a negative assessment of black people in general, as the generic nigga (line 1788) indicates and as the indication of a high quantity (line 1788: so many things) further underlines. As such, he implicitly puts forward and aligns with the negative stereotype of the 'lying nigga'. The interviewer briefly chuckles after this evaluation. The interviewee then continues by picking 
up an element from the story (line 1790) and evaluating it negatively again in a general sense, again referring to nigga by means of the third person singular pronoun he and attributing a lack of thought to him. After a brief pause, the interviewee then contrasts this negative evaluation with a positive evaluation of white people (line 1791: white man), thus constructing ethnicity as a relevant membership categorization device here. He even starts to elaborate further on this contrast by again initiating the topic of black people (line 1792: nigga), but his speech is overlapped by the interviewer who rephrases the interviewee's assertion about white people to formal English, as the reformulation of the interviewee's he ain't (line 1791) to he doesn't (line 1794) indicates. Furthermore, his contribution has the status of a question, as such thus constructing it as an understanding check and suggesting that the previous turn contained some kind of problematic utterance (Koshik, 2005). The interviewee then immediately latches on his response, which is not only provided by means of the negative particle no (line 1795), but also by a slightly rephrased repetition of his original assertion (line 1795). Both this negative particle and the repetition are repeated again in line 1796. After that, the interviewee returns to the topic of the ghost story again, but this time he distances himself personally from the content of this story, which is further underlined by means of the emphasized pronunciation of the first person pronoun (line 1798: $\uparrow \underline{I}$ ) and the temporal Extreme Case formulations (line 1798: never and in my life). This extract further underlines the complex web of the interviewee's alignments with social groups and the different criteria that are made relevant as the bases of the construction of these groups. These are constructed mainly by the interviewee, but they are also deconstructed and negotiated with the interviewer. This becomes particularly clear in the following part of the analyses.

\section{Post-Civil War period}


Considering Lomax's position as Assistant in Charge of the Archive of Folk Song of the Library of Congress and his interest in musicology, it is not surprising that many of the questions directed at the interviewee concern music. A constant theme throughout the interview is the mapping of ethnicity onto types of music, crudely giving the categories of black man's and white man's music. However, whilst the interviewee does sometimes align with such categorization work, this is often nuanced and the relevance of black and white master identities is often resisted and disaligned with as illustrated in the extract below.

\section{Extract 4:}

1686 IR Well this music you hear on the jukeboxes now

1687 and jazz, $\mathrm{d}=\mathrm{d}=\mathrm{do}$ you think that's colored

1688 people's music? Or do you think that's white

$1689 \quad$ people's music?

1690 IE Well, it's mixed.

1691 IR It is $\downarrow$

1692 IE It's really mixed (.) ${ }^{\circ}$ really, really mixed ${ }^{\circ}$

In line 1686, the interviewer asks whether he thinks jazz is colored people's music or white people's music. He thus sets up the categories black and the white in what Jayyusi (1984: 127) describes as an 'adversary or oppositional' pair which is occasioned as mutually exclusive. Thus black and white identities are set up as oppositional with mutually exclusive predicates (i.e. expectable features, characteristics, beliefs and so on) in terms of musical preference so that the predicate of liking jazz is either ascribed to black or white identities which talks into being the concept of black man's and white man's music. However, this identity work is resisted by the interviewee (line 1690: Well, it's mixed). The interviewer challenges this in the following line (It is $\downarrow$ ), but the interviewee reaffirms his opinion by 
adding a booster (really) and repeating his previous statement (line 1692: ${ }^{\circ}$ really, really really mixed $\left.^{\circ}\right)$. Moreover, after a slight pause he emphasizes this by repeating this booster twice.

However, as can be seen in the following example, at other times, the interviewer's projection of a black and white dichotomy is accepted, aligned with, and even elaborated upon by the interviewee.

\section{Extract 5:}

1219 IR Ah, do you think that the, ah (.5) the songs that the

1220 colored people sang were better than the songs that

1221 the white people sang ah? Do you like the songs better?

1222 Do you like the way Negro people sang them better?

1223 IE No. I tell you (.5). Now I tell you one thing

$1224 \quad(1)$

1225 IE a white man can't sing a song like a nigga.

1226 IR hmm

1227 IE Just can't do it (.) And he got (.) something in his head

1228 (.) he ain't learned that stuff (.) I heard a nigga tell a white

1229 man once (.) he said ah, he asked them, 'What you, what

1230 do you get of this Saturday Night thing?' Said, 'What do

1231 you get?' I said, 'Yeah.' ((taps cane)) He said, 'Man, if you

1232 get that trying be a nigga one night £trying to be a nigga

1233 one night£ you want to be a nigga a thousand days.'

1234 IR $\quad[(($ laughs $))]$

1235 IE [((laughs))] Say, 'Why?' He said, 'Get the best curriculum

1236 out on Saturday Night $£($ Jolly) anything in the world $£$. Rather

1237 be a nigga on Saturday Night.' 
1238 IR ((chuckles))

1239 IE I said, 'I ( ～） poor thing.' Ah he said, 'I want be a nigga.'

1240 'Darn fool, you ought to be £awfully crazy£.

1241 IR ((chuckles))

1242 IE Worst thing in the world.' Say, 'I'm sorry to be a nigga.'

1243 IR ((chuckles))

1244 IE $\quad \underline{\text { SORRY }}$

In line 1219, the interviewee asks if the interviewer likes the songs colored people sang and the way they sang them better than the whites. He thus, again, sets up mutually exclusive categorization for blacks and whites based on the types of songs they sang. The interviewer's formulation of his questions presents a favorable categorization for blacks, which is maintained throughout the double rephrasing of the original question (lines 1219-1222). This formulation demonstrates the interviewer's orientation to the supremacy of blacks regarding music, and thus to ethnicity as a relevant feature in this discussion.

At first, the interviewee disaligns with this racial stereotyping (line 1223: No. I tell you) but then he aligns with this identity work in the following lines when he states that: $a$ white man can't sing a song like a nigga (line 1225). Moreover, these differences are presented as being something that is in the Negro's head that he ain't learned (lines 12271228). This, therefore, mimics genetic theories of race so that certain predicates are occasioned as being natural features of the identity of black people and this is set up in opposition to the category of white people who cannot sing like niggas (line 1225) because implicitly they do not have the same natural predicates.

To prove his point, the interviewee then tells a story which underlines the 'fact' that blacks are better singers than whites by means of a constructed dialogue (Tannen, 1989) between a black man and a white man. As the interviewee delivers the white man's initial 
words (lines 1232-1233), he uses a smile voice which, according to Buttny (2001), consists of 'a markedly higher pitch and an intonational contour comparable to laughing during speaking but without any laughter tokens' (2001: 317). This achieves laughing at the white man which is category generated fun (Hester, 1996: 259) since the butt of the joke is a white man who wants to be a nigga and who, by wanting to be a nigga, displays predicates that are deviant to those normatively ascribed to whites. Moreover, by laughing in the next line (line 1234), the interviewee aligns with this (Jefferson, 1979: 83). The Negro protagonist then asks the white man why he wants to be a Negro and the white man replies that the Negro has the best curriculum out on Saturday night£(Jolly) anything in the world£. Rather be a nigga on a Saturday night (lines 1235-1236). As the interviewee delivers the white man's lines he does so again in a smile voice and this receives alignment from the interviewer who chuckles (line 1238). The interviewee then tells the coda of the story and provides two evaluations: he evaluates the white man as a darn fool and crazy (line 1240) and being black as the worst thing in the world, which again elicits alignment from the interviewer because of the chuckles. Thus the black identity is evaluated positively in terms of singing abilities and the identity white man is negatively evaluated, but nevertheless the final evaluation of the story is not favorable towards black ethnicity (line 1242: Worst thing in the world and sorry to be a nigga). In this evaluation, the word sorry is at first stressed and then repeated and stressed with volume higher than the surrounding talk for emphasis. So, whilst both the interviewee and the interviewer align through laughter to do 'laughing at' the white protagonist in the story thus suggesting that blacks are somehow 'smarter' than whites, the interviewee's final assessment is that being a nigga is not an enviable position after all.

However, even though the interviewee has positively evaluated the Negro's singing abilities and has made relevant ethnicity, at other times he is critical of what is talked into 
being as black music and disaligns with predicates (in this case liking blues music) which are occasioned as being ascribed to black identity.

\section{Extract 6:}

1458 IR Ah do you ah d=do you remember the first blues

1459 you heard that you didn't like? Do you

1460 remember what it was like? Do you

$1461 \quad$ re=remember when you first heard it and didn't

$1462 \quad$ like it?

$1463 \quad(3)$

1464 IE I don't know the first blues I heard.

$1465 \quad(4.5)$

1466 IE Oh I hear a little old boy sing that thing here. >I

1467 forget now anyhow < right here in $\mathrm{M}=$ Mound

$1468 \quad$ Bayou

1469 IR uhm

1470 IE Because that's something I didn't care for it was

1470 a little stupid for me. I didn't care nothing about

$1471 \quad$ it.

1472 IR A li=little stupid for you huh?

1473 IE Yeah $\underline{\operatorname{sir}}$ (.) Yeah sir (.) I don't care no kind of

1474 blues (.) didn't care nothing about it. I hear

1475 niggas niggas sing the blues and I didn't want to

1476 hear it.

1477 IR You didn't want to hear it?

1478 IE Never want to hear it (0.7) I think he is crazy 
1479 IR (laughs)

1480 IE that's right he is crazy

In line 1458, the interviewer shifts topic to the blues and asks three neutrally formulated questions in a series, but he also embeds a projection of the interviewee's negative evaluation of the blues in the questions (lines 1459 and 1462: and didn't like it). After a three second pause, the interviewee replies that he doesn't know when he first heard the blues and then after another long pause (4,5 seconds) he vaguely recounts when he first heard the blues. The interviewee then aligns with the negative assessment projected by the interviewer (line 1470: I didn't care for it was a little stupid for me. I didn't care nothing about it). The interviewer repeats the assessment with rising intonation. As Koshik points out, 'repetitions can be heard as targeting a trouble source in the prior utterance for the recipient to self-correct, especially when contrasted stress is added to the target error' (2005: 114). This assessment thus implicitly points at the interviewer's disalignment with this statement, since it provides the interviewee with an opportunity to correct himself. However, in this case no correction is forthcoming and a further negative assessment of the blues is provided in line 1474. In the continuation of the turn, he states that niggas sing the blues but that he didn't want to hear it (lines 1475-1476). On the one hand, this makes relevant the dichotomy between black and white music, thus foregrounding ethnicity as a relevant feature of the interaction, but on the other hand, the interviewee disaligns with the predicate of liking blues music attributed to the identity 'black'. Thus whilst he ascribes black identity to liking blues music, he immediately distances himself from it. The interviewer then repeats the interviewee's turn with rising intonation (line 1477: You didn't want to hear it?). This is again hearable as orienting to the interviewee's prior turn as a trouble source, but the interviewee once more does not repair his turn and he repeats the fact that he never want to hear it (line 1478) and adds the assessment that he [the blues singer] is crazy (line 1478). This elicits laughter in the following turn 
which, since it is not reciprocated, is oriented to by the interviewee as doing disalignment and not accepting his assessment as serious (Glenn, 2003: 141). In the next turn, the interviewee repeats his negative assessment (line 1480: that's right he is crazy). Thus, having negatively assessed the blues singer and explicitly making relevant the singer's ethnic identity as a nigga, the interviewee distances himself from the link between black identity and musical tastes (in this case the blues). This distancing is highlighted in the continuation of the extract as discussed below.

\section{Extract 7:}

1481 IR £what did it sound like£

1482 IE Oh it wasn't sound like nothing just some old (.)

1483 oh lord most of it wasn't nothing. Just (.5) some

1484 negroes (.) > negro acting monkey < (.) Nigga

1485 act like he got shortcoming. That's right. He

1486 shortcoming. He uncouth (.) See个 (.) Nigga

1487 ain't got some kind of stuff in his head. Why he

1488 just going to be er: (.3) a monkey all his life

1489 right? care about it.

1490 IR Naw, I like the blues.

1491 IE You do $\uparrow$ I don't care nothing about it.

1492 IR ((slight laughter))

1493 IE nothing (.7) nothing about it want to get me to

1494 know something=like something you get a brass

1495 band start let's go do a quickmarch out there

1496 show you what I'll do (.) quickmarch 
In line 1481, the interviewer asks what the music sounded like. In reply to this question, the interviewee dismisses the blues as nothing but then, explicitly linking the blues music to ethnicity, he criticizes the Negroes (lines 1484-1486: acting monkey, like he got shortcoming and being uncouth) and he ends with the assessment that if a nigga ain't got some kind of stuff in his head he just going to be er: (0.3) a monkey all his life right? (lines 1487-1489). The use of the Extreme Case formulation all his life (Pomerantz, 1986) emphasizes the truth of the assessment. The interviewee thus distances himself from black identity with the ascribed predicate of liking blues music. The interviewer then explicitly disaligns with this assessment (line 1490: Naw, I like the blues) which, as indicated by the emphasis and rising intonation (line 1494: You do $\mathrm{\uparrow}$ ), elicits surprise from the interviewee. In the next line, the interviewer gives a slight laugh which is oriented to as disalignment since it is not reciprocated and in the following line the interviewee repeats his negative assessment (line 1493). The interviewee then, in contrast to his expressed dislike of the blues, implicitly displays his like of brass band

music since he offers to play a quickmarch. The fact that the interviewee expresses his like for brass band music makes relevant an identity that contradicts the idea of black and white people's music because band music is often occasioned as white people's music. For example, the interviewee has already noted that he [Jefferson Davis] organized that band for his Negroes (line 230) and the band used to escort [Jefferson Davis] everywhere he went (line 235) and that the band is often occasioned as being for white people as seen in the following extract.

\section{Extract 8:}

755 IR $\quad \mathrm{w}=\mathrm{w}=$ what kind of what kind of what kind of music $\mathrm{d}=$ did did they have? Did they have the same you had? or did they 758 have different songs you played[ for them?] 
760 they we $=$ we $=$ we played just the string

761 band. Me and the brass band played for

762 white folk. They'd have a big outing, you

763 understand. In their lawn. We played music

764 for them, you understand. Brass band

765 music, you know.

766 IR uhu

In line 755 , the interviewer asks what kind of music they (the whites) had, as such continuing the dichotomy of white and black music and highlighting it by means of an us-them opposition (cf. Leudar, Marsland and Nekvapil, 2004). At first, the interviewee provides an unfocused disalignment (line 759: naw) and then reformulates the they-pronoun to a wepronoun, which demonstrates his struggle with the interviewer's dichotomous presentation of the relation between music and ethnicity. He then rephrases this dichotomy to an opposition between musicians (line 761: me and the brass band; line 763: we) and audience, which is constructed as white (line 761-762: (the band) played for white folk; line 762: they; line 764: them). Thus, whilst in his initial question (line 755), the interviewer makes relevant the oppositional pairs black and white, through the predicates of musical taste ascribed to these identities, the interviewee disaligns with these predicates by identifying himself with white man's music (brass band) rather than black man's music (the blues). So in conclusion, this section was characterized by a web of different alignments by the interviewee which either ratified or challenged the relation between ethnicity and musical talents and tastes that was mainly talked into being by the interviewer.

\section{Discussion and conclusions}


In this article we focused on the way social groups were constructed and we looked into the way these constructions are related to ethnicity. We aimed to foreground the collaborative work that is done both by the interviewer and the interviewee in talking these social groups into being. The importance of this emphasis on the interactional nature of these group memberships was most clearly demonstrated in the second part of the analyses, which is characterized by an interviewer who frequently foregrounds ethnicity as a relevant feature of the discussion of music and musical tastes. Moreover, he explicitly presents himself as a fan of music that is constructed as typical of black people such as blues music and this explicit statement is strongly contrasted with the interviewee's opinion, thus clearly taking the form of a dispreferred reaction in this particular context (extract 7). Furthermore, the interviewer also implicitly talks himself into being as ideologically in favor of black people. This is demonstrated throughout the interview by the way the interviewer formulates his questions (see for example extract 5) or by means of the interviewer's evaluations of, and his reactions to, the interviewee's contributions. For example, on numerous occasions in the interview (see e.g. extracts 3, 6 and 7), he implicitly marks his disalignment with some of the interviewee's statements that are negative about typical black music or about black people in general. Thus we can conclude that this interviewer does not take a neutral stance regarding ethnicity in this interview.

Further, as was discussed in the introduction, this was a fairly typical attitude of interviewers, but given its higher frequency - and often more problematic nature -, this point is mainly raised regarding white interviewers who of course took the opposite stance and spoke in a disrespectful way to the black interviewees (Vann Woodward, 1991). This construction of the interviewer's favorable position towards black music and black people of course has an important influence on the stories that are elicited and the stances that are taken during the interview, since this is a collaborative endeavor of both the interviewer and the 
interviewee. As such, this analysis forms a nice illustration of the influence researchers have on the data they collect, as De Fina (2011) already pointed out. Furthermore, our analyses demonstrate that the interviewee partially resists the joint construction of this ideological stance. More than once, the interviewee provides dispreferred responses to the interviewer's sometimes suggestive questions, and he is found to shift between aligning and disaligning with the construction of ethnicity as a relevant feature in the interview. This results in a multifaceted construction of group membership, which is based on quite diverging grounds, ranging from ethnicity, through admiration for a person as a grouping device (admirers of Jefferson Davis) to involvement in music (musicians versus audience).

This fluidity in alignments is not particularly related to the period under discussion, and so the social systems that form the contexts of these two parts of the interview are of no specific influence on the way this topic is being dealt with. So, for example, even in spite of the membership of the group of slaves, which coincides with the ethnic group, the interviewee sometimes explicitly distances himself from this group (see e.g. extract 3 ). This lack of difference between the two periods may be due to several reasons. First of all, at the time of the interview, racial inequality was still a fact, embedded in society by means of the Jim Crow laws. The interviewee may thus have experienced little difference in attitudes towards ethnicity between the antebellum and postbellum periods and thus not much difference is reflected in the discussion of these two periods. Secondly, context does not simply exist 'out there, waiting to be transferred to history books, rather it is a subjective construct (Van Dijk, 2008; 2009): especially given the interviewee's positive perception of the slave system, as is implicitly demonstrated in the first extracts of the analyses and as personified in the construction of the 'benevolent' master Jefferson Davis, it is not surprising that the interviewee's categorizations do not reflect the harsh social and ethnic criteria that the slave system was based on. Thirdly, the interviewee was a child at the time of the slave system and 
that is typically a period in which group memberships are in development until 'in late adolescence and young adulthood', people begin 'to construe their lives as evolving stories that integrate the reconstructed past and the imagined future' (McAdams, 2006: 13). The interviewee's sense of belonging to a particular social group was thus probably still not yet fixed during the antebellum period. Fourthly, retelling one's life story is not a cumulative process, in which recent fragments are gradually added without any consideration of what the function of these stories is for the ongoing interaction. Instead, it is a process of constant revision (Linde, 1993: 3) which happens in the here and now of collaboratively performing and negotiating the story with the interviewer and which also does argumentative work, in this case mainly refuting the interviewer's stance. As we have demonstrated, the latter has a significant influence on the selection of the stories and the negotiation of the stances that are talked into being through them, while the interviewee is also managing other typical requirements related to storytelling, such as considerations of credibility and tellability (Labov, 1982; Norrick, 2005) and the need to make stories coherent 'by the moral comments they offer on the way things are, the way things ought to be, and (most especially) the kind of person the speaker claims to be' (Linde, 1993: 8). So, actually, the lack of consistency in the interviewee's alignments is what makes this narrative as a whole coherent, since it demonstrates that both in the discussion of the past and the present, this interviewee is a person who is critical of monolithic group memberships. Since this seems to be the stance of the interviewer however, the interviewee's selection of the different stories is thus oriented to refuting such ethnically based group memberships. Interestingly, the interviewee constructs this ideological stance both for himself (in the second part of the interview) and for others (mainly in the first part of the interview since this part is mostly characterized by hearsay stories in which the interviewee did not play a role himself). So his self-alignments in the 
present of the interview and his other-alignments in the slavery past reflect one another, thus clearly demonstrating the reflexive property of narrative.

However, the different genres that are found in these two parts of the interview have implications regarding the way group memberships are talked into being. This is directly related to the importance of the role of the interviewer and the degree to which the data can be regarded as interactional. The first part is characterized by extended turns in which stories with a particular point are presented to the interviewer, whose turns are usually situated before or after the actual story. Even in this case, the interviewer's role should not be underestimated, since for instance the selection of a particular topic is essential to the development of the story. However, while telling the story, the interviewee usually constructed and developed the story without any explicit challenges by the interviewer and thus his constructions of social groups do not fluctuate as frequently as in the second part of the interview. Since in this part, the turns are much shorter and more explicit challenges by the interviewer occur, there is more opportunity for the interlocutors to negotiate and shift alignments. Indirectly, this difference based on genres is related to the specific context that these parts of the interview are related to, since the first part is about a topic in which the interviewee clearly has epistemic primacy because of his direct, though fairly limited, access to knowledge (Pomerantz, 1984). This first-hand knowledge far surpasses the access the interviewer, who was not even born at the time under discussion, had. In the second part, this clear division of access to knowledge is absent and so the topics are much more open for negotiation by the two interlocutors who can both contribute to the construction of knowledge because of their fairly similar epistemic statuses (Moita-Lopes, 2006: 305).

So the analyses in this article illustrated the importance of looking at narratives as interactional achievements in which an element such as group membership and its relation to ethnicity is extensively negotiated by the interlocutors. The genre differences between the two 
periods under discussion demonstrated that these entail different degrees of negotiation and this is directly related to the fact that the different genres are embedded in the different periods under discussion. Both periods imply different epistemic statuses for the interviewer and so indirectly, the shift in time frame and context plays an important role in the way these stories were developed and the extent to which they were collaboratively achieved. Interestingly, it is the shift in epistemic status of the interviewer that triggers these different genres and thus, as De Fina notes, it is not enough to just point 'to the role of the interviewer in positioning the interviewee' (De Fina, 2009: 254), but the implications of this role need to be considered as thoroughly as possible in order to provide a more nuanced account of the way stories are elicited, shaped and negotiated throughout the interview.

\section{References}

Antaki C (2002) An Introductory Tutorial in Conversation Analysis. Available at: http://www-staff.lboro.ac.uk/ssca1/notation.htm.

Atkinson P and Delamont S (2006) Rescuing narrative from qualitative research. Narrative Inquiry 16 (1): 164-172.

Bailey DT (1980) A divided prism: Two sources of black testimony on slavery. The Journal of Southern History 46 (3): 381-404.

Baynham M (2006) Performing self, narrative and commuity in Moroccan narratives of migration and settlement. In: De Fina A, Schiffrin D and Bamberg M (eds) Discourse and Identity, Studies in Interactional Sociolinguistics 23. Cambridge University Press: Cambridge, 376-397. 
Blassingame JW (1972) The Slave Community: Plantation Life in the Antebellum South. New York: Oxford University Press.

Blassingame JW (1975) Using the Testimony of Ex-Slaves: Approaches and Problems. The Journal of Southern History 41 (4): 473-492.

Brown SA (1991) On Dialect Usage. In: Davis CT and Gates HLJ (eds) The slave's narrative. New York: Oxford University Press, 37-39.

Buttny R (2001) Therapeutic humor in retelling the clients' tellings. Text 21 (3): 303-327.

Carranza IE (1998) Low-Narrativity Narratives and Argumentation Narrative Inquiry 8 (2): 287-317.

Cohen RD (ed.) (2011). Alan Lomax, Assistant in Charge of the Library of Congress: Letters 1935-1945. Pages.: University Press of Mississippi.

De Fina A (2009) Narratives in interview - The case of accounts; For an interactional approach to narrative genres. Narrative Inquiry 19 (2): 233-258.

De Fina A (2011) Researcher and informant roles in narrative interactions: Constructions of belonging and foreign-ness. Language in Society 40: 27-38.

Edwards D and Potter J (1992) Discursive Psychology. Sage: London.

Escott PD (1991) The Art and Science of Reading WPA Slave Narratives. In: Davis CT and Gates HLJ (eds) The slave's narrative. New York: Oxford University Press, 40-47. Georgakopoulou A (2007) Small Stories, Interaction and Identities. John Benjamins: Amsterdam.

Glenn P (2003) Laughter in Interaction. Cambridge, U.K.: Cambridge University Press. Hamilton M (2001) The blues, the folk, and African-American history. Transactions of the Royal Historical Society 11: 17-35.

Hester S (1996) Laughter in its place. In: Paton GEC, Powell C and Wagg S (eds) The Social Faces of Humour. Practices and Issues. Aldershot, England: Arena, 243-270. 
Hester S and Eglin P (1997a) Membership categorization analysis: an introduction. In: Hester $\mathrm{S}$ and Eglin P (eds) Culture in action: studies in membership categorization analysis. Washington, D.C.: University Press of America, 1-24.

Hester S and Eglin P (1997b) Conclusion: Membership categorization analysis and sociology. In: Hester S and Eglin P (eds) Culture in action: studies in membership categorization analysis. Washington, D.C.: University Press of America, 153-164.

Holstein JA and Gubrium JF (2003) Active interviewing. In: Holstein JA and Gubrium JF (eds) Postmodern Interviewing. Thousand Oaks, CA: Sage, 67-80.

Housley W and Fitzgerald R (2002) The reconsidered model of membership categorization analysis. Qualitative Research 2: 59-83.

Jayyusi L (1984) Categorization and the Moral Order. Routledge: Boston.

Jefferson G (1979) A technique for inviting laughter and its subsequent acceptance/declination. In: Psathas G (ed.) Everyday Language: Studies in Ethnomethodology. New York: Irvington, 79-96.

Koshik I (2005) Beyond Rhetorical Questions. Assertive Questions in Everyday Interaction. Amsterdam/Philadelphia: John Benjamins.

Labov W (1982) Speech Actions and Reactions in Personal Narrative. In: Tannen D (ed.), Analyzing Discourse: Text and Talk. Georgetown University Press: Washington DC, $219-247$.

Lepper G (2000) Categories in text and talk: a practical introduction to categorization analysis. London: Sage.

Leudar I, Marsland V and Nekvapil J (2004) On membership categorization: 'us', 'them' and 'doing violence' in political discourse. Discourse \& Society 15 (2-3): 243-266.

Library of Congress (2011) The Library of Congress/Fisk University Mississippi Delta Collection. Available at: http://www.loc.gov/folklife/guides/fisk.html. 
Linde C (1993) Life Stories, the creation of coherence. Oxford University Press: New York / Oxford.

Lomax A (1993) The Land Where the Blues Began. New York: Pantheon Books.

Lynch M and Bogen D (2005) "My memory has been shredded": a non-cognitivist investigation of 'mental' phenomena. In: Te Molder H and Potter J (eds) Conversation and Cognition. Cambridge, U.K.: Cambridge University Press, 226-240.

McAdams DP (2006) The role of narrative in personality psychology today. Narrative Inquiry 16(1): 11-18.

Moita-Lopes LP (2006) On being white, heterosexual and male in a Brazilian school:multiple positionings in oral narratives. In: De Fina A, Schiffrin D and Bamberg M (eds) Discourse and Identity, Studies in Interactional Sociolinguistics 23. Cambridge University Press: Cambridge, 288-313.

Norrick NR (2005) The dark side of tellability. Narrative Inquiry 15 (2): 323-343.

Pomerantz A (1984) Giving a source or basis: the practice in conversation of telling "how I know". Journal of Pragmatics 8: 607-625.

Pomerantz A (1986) Extreme Case formulations: A way of legitimizing claims. Human Studies 9: 219-229.

Potter J and Wetherell M (1987) Discourse and Social Psychology, Beyond Attitudes and Behaviour. Sage: London.

Puckett NN (1990) Names of the American Negro Slaves. In: Dundes A (ed.) Mother Wit from the Laughing Barrel. Readings in the Interpretation of Afro-American Folklore. Jackson and London: University Press of Mississippi, 156-174.

Sacks H (1972) An initial investigation of the usability of conversational data for doing sociology. In: Sudnow D (ed.) Studies in social interaction. New York: Free Press, 3174 
Sacks H (1986) On the analyzability of stories by children. In: Gumperz JJ and Hymes D (eds) Directions in sociolinguistics: the ethnography of communication. Oxford: Basil Blackwell, 325-345.

Sacks H (1992) Lectures on conversation. 2 vols. Edited by Gail Jefferson with introductions by Emanuel A. Schegloff. Oxford: Basil Blackwell.

Schaeffer NC and Maynard DW (2005) From paradigm to prototype and back again: interactive aspects of 'cognitive processing' in standardized survey interviews. In: Te Molder H and Potter J (eds) Conversation and Cognition. Cambridge, U.K.: Cambridge University Press, 114-133.

Schegloff E (2007) A tutorial on membership categorization. Journal of Pragmatics 39: 462482.

Schriffin D (1993) "Speaking for another” in sociolinguistic interviews: Alignments, identities, and frames. In: Tannen D (ed.) Framing in Discourse. New York: Oxford University Press, 231-263.

Sekora J (1987) Black message/white envelope. Genre, authenticity, and authority in the antebellum slave narratives. Callaloo 32 (3): 482-515.

Soapes T (1977) The Federal Writers' Project Slave interviews. Useful data or misleading source. The Oral History Review 5 (1): 33-38.

Spindel DJ (1996) Assessing memory. 20th Century slave narratives reconsidered. Journal of Interdisciplinary History 27 (2): 247-261.

Stivers T (2007) Alternative recognitionals in person reference. In: Enfield N and Stivers T (eds) Person Reference in Interaction: Linguistic, Cultural and Social Perspectives. Cambridge, U.K.: Cambridge University Press, 73-96.

Tannen D (1989) Talking Voices, Repetition, dialogue, and imagery in conversational discourse. Cambridge University Press: Cambridge. 
Van De Mieroop D and Clifton J (2011) Standardized relational pairs in interviews with former slaves; Construction, negotation and alignment. Narrative Inquiry 21 (1): 4467.

Van Dijk TA (2008) Discourse and Context, A Sociocognitive Approach. Cambridge: Cambridge University Press.

Van Dijk TA (2009) Society and Discourse, How Social Contexts Influence Text and Talk. Cambridge: Cambridge University Press.

Vann Woodward C (1991) History from Slave Sources. In: Davis CT and Gates HLJ (eds) The slave's narrative. New York: Oxford University Press, 48-59.

Wetherell M and Maybin J (1996) The distributed self: a social constructionist perspective. In: Stevens R (ed.), Understanding the self. Sage: London, 219-279.

Wetherell M and Potter J (1992) Mapping the language of racism, Discourse and the legitimation of exploitation. Harvester Wheatsheaf: New York.

Whooley O (2006) The political work of narratives; A dialogic analysis of two slave narratives. Narrative Inquiry 16 (2): 295-318.

Yetman NR (1967) The background of the slave narrative collection. American Quarterly 19 (3): 534-553.

Yetman, N (1984) Ex-slave interviews and the historiography of slavery. American Quarterly 36 (2): 181-210.

Zimmerman DH (1988) On Conversation: The Conversation Analytic Perspective. Communication Yearbook 11: published annually for the International Communication Association. Sage: Newbury Park, 406-432.

Zimmerman DH (1998) Identity, Context and Interaction. In: Antaki C and Widdicombe S (eds) Identities in Talk. Sage: London, 87-106. 


\section{Notes}

'See the section 'Research question' for an overview of the different genres that occur in the interview under study.

${ }^{\text {ii }}$ As part of the New Deal, the Works Progress Administration (WPA) sponsored a Federal Writers Project which put unemployed writers to work collecting narratives of American life, including many interviews with ex-slaves.

iii The deep link is: http://memory.loc.gov/ammem/collections/voices/vfsabout.html.

iv The deep link to this interview is: http://memory.loc.gov/cgibin/query/S?ammem/afcesnbib:@field\%28AUTHOR+@od1\%28Johnson,+George+\%29\%29 (last consulted on 28 April 2011). The authors would like to thank the Library of Congress for making these recordings and transcripts available online.

${ }^{\mathrm{v}}$ Some questions may however point in this direction, as is for example the case in extract 3 when the topic of ghost stories is discussed.

${ }^{\text {vi }}$ The transcription follows the Jefferson system, as for example explained by Antaki (2002).

${ }^{\text {vii }}$ The exact meaning of the complicated action of this story remains rather unclear and thus we decided not to go into that. Since it is clear from the rest of the interview that white people admired Jefferson Davis as well (for example in line 959-961: 'The white people come down there in their hacks on steamboats just to see master Jeff's plantation, you understand.') and since the abstract and coda are quite explicit, this does not pose too much problems for the interpretation of this extract. 